\title{
The Environmental Dimensions of Islam
}

\author{
Mowil Izzi Dien \\ Cambridge: The Luttenvorth Press, 2000. 190 pages.
}

Dr. Mawil Izzi Dien, Senior Lecturer in Islamic Studies at the University of Wales, has been writing about Islam and environmental issues for almost two decades. The Environmental Dimensions of Islam is a summary of his previous writings presented together with new additions. Izzi Dien is one of the most prominent scholars in the new discourse of Islamic ecotheology, although he himself seldom refers to other Muslim scholars in this field, which somehow gives the wrong impression that he is the only one among Muslims dealing with environmental issues.

After a short introductory chapter, Izzi Dien discusses in chapter 2 "The Environment and Its Components in Islam." This chapter gives an informative introduction to Qur'anic terminology on various environmental components and their status in Islam, such as water, earth, living organisms, diversity and biogeological cycles.

This Qur'anic terminology is further developed in chapter 3, dealing with theology pertaining to the environment. This chapter deals with issues such as the question of creation and the unseen and the Divine origin of everything: constancy, comprehensiveness, balance, and universal laws in nature as the Creation. I sympathize with much of the argument presented regarding the role of human beings in Creation, i.e., their trusteeship, partnership and responsibility. This chapter would have been strengthened by a discussion of the accusations from the environmental movement that the monotheistic religions represent an anthropocentric, and thus problematic, view of nature. For instance, the idea expressed in the Qur'an that God made nature subservient (rakhkhara) to human beings may be criticized (see Qur'anic verses 2:29; 45:12-13; and 14:33-34), but the author chooses not to discuss this concept at all or to refer to other scholars' criticisms.

Another problem is his unusual definition of positivism, a philosophy held accountable for promoting a hegemonic position of science associated with a problematic view of nature. He sees positivism as something that Islam promotes, as in his view, it implies that human beings "are an active, positive force placed on this earth to construct, improve, and reform it." In the Qur'an we read about examples of how people who destroyed their own habitat were punished by God in the form of ecocatastrophes. 
Islamic environmental ethics are presented and elaborated upon in chapter 4. Izzi Dien discusses the concept of hurma, meaning the sanctity of God's creation. This chapter delivers important environmental arguments, and the author suggests how the Islamic administrative system (hisba) and customs (urf) can be useful tools in formulating a practical environmental ethic. A problem here is that Izzi Dien views environmental problems mainly as the conservation of nature, which is really only one among the whole complexity of problems associated with the contemporary human-environmental relationship. Today, "conservation of nature" is less problematic in richer nations that can "afford" to set aside nature reserves. Developing countries, of which many are Muslim, often have heavy debt burdens and are forced to exploit their natural resources in a non sustainable manner. This is not a problem of ethics, but rather of brute economic facts faced by poor countries.

Chapter 5 presents Islamic legal perspectives on the environment, in which the author discusses the sources of Islamic law. While the author argued in the previous chapter that in Islam there should be no separation between ethics and law, this problematic separation is maintained here. However, it seems that what is presented as "legal" in chapter 5 might as well be understood as "ethical." It must be stressed that unfortunately environmental issues have been neglected by contemporary Islamic scholars, and that there is uncertainty about what Islamic law really says on certain environmental issues. Is nuclear power allowed in Islam? Shall we accept genetic engineering? After the alarms of the mad cow disease (Bovine Spongiform Encephalopathy) and Creutzfeldt-Jakob disease should we not classify it haram to eat meat from animals given feed-stuff of animal origin, based on the Islamic principle that we are not allowed to eat beasts of prey?

Izzi Dien could have made an excellent contribution here in elaborating what Islamic law/ethics can say on these matters, if he had chosen to discuss some practical issues and not only some general principles. He presents some "legal maxims" that should guide Muslims on issues pertaining to environmental dilemmas. These principles are too vague, general and do not specify what Muslims are supposed to do. For instance, we may all agree on the principles of "no harm should be inflicted or retaliated" and "what has been allowed by necessity should be measured by that necessity and nothing more," but these are definitely open to many subjective interpretations on what is meant by "harm" and "necessity." 
Izzi Dien's strength is in his training in the Arabic language and Islamic thought, rather than in his understanding of environmental problems, which is weak and simplified. His references to academic work on environmental issues are few and not the most prominent in the field. This raises the issue of how Muslim scholars in the global era must have at least two bodies of knowledge: Islamic and academic, in the fields they wish to explore. This fact becomes apparent in chapter 6, on Islamic economic justice and the environment, where the author's ignorance on the economicecological reality becomes almost embarrassing. He writes for instance that:

If humans were, for example, by genetic manipulation, to obtain the ability to digest cellulose and be able to derive benefit from eating grass, then there would not be any grass left for sheep, horses and other animals.

Surely, this is not the major ethical problem facing us with genetic manipulation, and is certainly not an issue in the debate! Further, in contemporary environmental debate, excessive material consumption is considered to be the most important contribution to ecological disaster. Izzi Dien states (with reference to Asqalani) that: "consumption is a behavior without destructive enmity but rather constructive competition." In my view, there are several arguments in favor of a problematization regarding consumerism.

In chapter 7, environmental protection is discussed in relation to the public interest, and here again the author discusses in a general manner the social conditions of environmental dilemmas, without giving any clear-cut answers. When he discusses species conservation he states that vegetarianism is not permitted in Islam. Although I agree that vegetarianism is not encouraged in Islam, I believe we cannot state that it is not allowed if such action is chosen based on a personal conviction of preventing the suffering of animals.

Chapter 9 is devoted to nature conservation, and Izzi Dien compares "The World Charter for Nature" (WCN) outlined by the General Assembly of the UN, with what is referred to as IPCNE - the Islamic Principles for the Conservation of the Natural Environment. IPCNE was a paper produced in 1983 by a team of scholars including Izzi Dien with the objective of helping Muslim countries develop environmental legislation. This was an admirable and important effort.

Here, the author makes the mistake of presenting his own subjective interpretation of Islamic sources as an objective fact - a problem throughout the book, and one of my main concerns with the book. The IPCNE has 
not, as far as I know, been negotiated among Muslims, nor signed or ratified by Muslim states. Both the WCN and the IPCNE reveal the paradox in environmental protection: any formulation must be vague and general in order to be accepted by the majority, but statements that are not specified and exact are useless in practical environmental work. Further, the author demonstrates again that he is unaware of the critical debate that followed the Rio meeting in 1992. Izzi Dien accepts uncritically, for instance, the concept "sustainable development," and is apparently not aware of debates classifying the term as an oxymoron (i.e., development and sustainability as a contradiction in terms).

The last chapter is a conclusion based on a list of 12 Islamic environmental principles and is basically a summary of the arguments presented in the book. I have no objections to these conclusions in general, but the book leaves me with the feeling that there are more controversial issues left to be explored on the subject of Islam and the environment. Muslims must realize that we are facing some really difficult questions in this field and scholars must show their responsibility in this issue. Izzi Dien's book is a welcome and appreciated contribution in line with these efforts in spite of its shortcomings discussed in this review. In addition, this book gives a valuable glossary of Arabic terms related to the environment.

Soumaya Pernilla Ouis Human Ecology Division Lund University Lund, Sweden 